The University of Southern Mississippi

The Aquila Digital Community

Faculty Publications

$12-1-2010$

\title{
The Early American Table: Food and Society in the New World
}

Andrew P. Haley

University of Southern Mississippi, andrew.haley@usm.edu

Follow this and additional works at: https://aquila.usm.edu/fac_pubs

Part of the History Commons

\section{Recommended Citation}

Haley, A. P. (2010). The Early American Table: Food and Society in the New World. Journal of World History, 21(4), 751-754.

Available at: https://aquila.usm.edu/fac_pubs/865

This Book Review is brought to you for free and open access by The Aquila Digital Community. It has been accepted for inclusion in Faculty Publications by an authorized administrator of The Aquila Digital Community. For more information, please contact Joshua.Cromwell@usm.edu. 
that accompanied Old World encounters with them. Such even-handedness tends to make Norton's conclusions about these "first commodity fetishes of the modern world" (p. i2) all the more persuasive, as does the consistent clarity and elegance of her prose. (Jargon-filled sentences that betray her study's origins in the rarified air of Berkeley seminar rooms are exceedingly rare.) Her dense final chapter, "Enchanting the Profane," exemplifies these merits. Obviously, she admits, one cannot disaggregate the precise weight her titular commodities played in the gradual desacralization of Spanish culture. But while scholars have long focused on the secularizing effects of internal developments like the Reformation and early modern state formation, she convincingly argues that "European expansion and its by-products must now be included" among the reasons for such transformations (p. 255). By carefully elaborating this and other claims about the multidirectional character of exchanges between Europe and the Americas-yet without exaggerating them-Norton has presented readers with a sophisticated example of Atlantic history at its finest.

SCOTT P. MARLER

University of Memphis

The Early American Table: Food and Society in the New World. By trudy eden. DeKalb: Northern Illinois University Press, 2008. 203 pp. \$37.00 (cloth).

For Europeans settling in newly "discovered" British North America, the colonies offered vast lands and rich opportunities to experiment with food. The choices that settlers made about what to plant spoke to their aspirations for both a new existence, freed of the conventions of European life, and their eagerness to preserve, even when nature resisted, the traditions of home. How and what colonial Americans ate has received increasing attention from scholars in recent years, and most have concluded, with a touch of patriotic zeal, that ties to the Old World were ultimately not strong enough to keep newly minted Americans from exploiting the culinary opportunities that North America offered. With the publication of The Early American Table, Trudy Eden muddies the water, suggesting that America's revolution in dining was as influenced by new European philosophical ideas about food as it was influenced by first contact, geography, or nascent revolutionary fervor.

To make her case, Eden embarks on two concurrent investigations. Eden's intellectual history of the philosophy of man and food leads us 
from ancient Greece to King George's England, spanning thousands of years and the Atlantic Ocean. Simultaneously, her social history of the American colonies seeks to demonstrate the efficacy of these ideas. Eden wants to show that ideas about food that were in wide circulation throughout Europe played a central role in determining how American colonists ate and set the stage for America's revolutionary embrace of abundance. Bringing these two projects together into a coherent argument, however, proves tricky.

When the first Europeans arrived in what would become British North America, Eden argues, their diets were governed by a humoral conception of the body in which combinations of heat and moisture, regulated in large part by diet, determined not only health, but also status. Humoral philosophy held that diet consisted of four natural elements, and in the mother country as well as in America, it was widely believed that virtue, economic success, and race were a reflection of what you consumed. Eating like a prince made you a prince; to eat like one of the savage natives of North America was to risk becoming a savage.

The humoral order ruled supreme until the Scientific Revolution, and then, in fits and starts, the idea of the mechanical body displaced it. Increasingly it was understood that the heart was a pump and the stomach a crucible, and that chemistry, rather than temperature and moisture, determined what a person should and should not eat. This new approach to science and health, first widely publicized in the English-language world by George Cheyne in I 724 , did not radically alter what the English ate at home or abroad, but it did change what it meant to eat well. The humoral idea had encouraged the belief that eating particular foods produced virtue, a theory that equated moral superiority with wealth, given that a heavy purse was often necessary to secure a diet that could lead to ethical perfection. The mechanical philosophy, in contrast, was more democratic. Everyone had basically the same biology, and almost anyone could achieve some degree of balance between good foods and bad. Diet no longer produced virtue; rather, moral merit was evidenced by the discipline required to maintain a healthy diet.

Eden's extensive research into ideas about diet in English-language philosophical and scientific texts in the seventeenth and eighteenth centuries produces a fascinating study of how the Scientific Revolution changed the meaning of eating. Although Eden's investigation of the mechanical body is cut short by the book's adherence to a political timeline (the book ends with the American Revolution, not the complete acceptance of the mechanical way of thinking about food), Eden's efforts to link scientific transformations to the virtue of attain- 
ing the "golden mean" and eventually to democratization are provocative. However, the book's intellectual history of food is unintentionally undermined by the second project that Eden undertakes in The Early American Table: the uneven and often contradictory effort to link dietary advice to the lived lives of colonists.

Americans were too busy establishing a foothold in a strange land to muse about the inner workings of the body. To link European intellectual ideas to the lives of American colonists, Eden examines the culinary experiences of settlers from Jamestown to the American Revolution and attributes the food choices they made to either the humoral or the mechanical philosophy. We learn that settlers in Plymouth were more willing to defy convention and implement a social "golden mean" in addressing inequality and scarcity than the colonists at Jamestown, we explore the angst of notables such as Cotton Mather and William Byrd II as mechanical ideas of the body undermined the humoral concepts of virtue they had been raised with, and we engage in an experiment in the possibilities of abundance with members of the Tuesday Club, an Annapolis, Maryland, Republican political club. In each case, Eden finds evidence that humoral or mechanical notions of health and virtue determined food choices.

As anyone who has written about the history of eating eventually realizes, people occasionally record what they eat, but they rarely leave clear records about why they chose to eat the foods they did. As a result, Eden is forced to treat "you are what you eat" as a behavioral dictum and interpret diets as evidence of philosophical commitment. This makes her conclusions highly speculative and sometimes inconclusive. Since the same humoral ideas presumably influenced the settlers at Plymouth and Jamestown, Eden - who rarely addresses causes that are not directly related to perceptions of food's transformative capacity-struggles to explain why the two colonies behaved differently in the face of scarcity. In the end, the usefulness of the comparison is not clear. In other cases, explanations of people's behavior-although always intriguing - seem unjustified by the evidence. In discussing the Tuesday Club's back-and-forth debate over the level of luxury they should allow themselves at their meetings, Eden sees the emergence of a sort of premodern relativism that refuses to proscribe a single menu for every member or to judge a man based on what he eats. This relativism, she claims somewhat cryptically, might explain the need for a two-party system in America (p. I 4I). But her evidence does not offer the clear blueprint her conclusions require. When Charles Cole openly violated the club's rules by providing luxuries, he was elected the club's leader, and clubmen who could not provide sufficient victuals were 
excluded; when the "Orator" launched an impassioned defense of the simplicity of hominy, his pleas were met with apathy. Luxury, not balance, won out. In another chapter, Eden sees in the "yeoman" farmer Charles Carroll's acquisition of elaborate but plain house wares, evidence that the Carrolls were seeking a culinary "golden mean" while hoping that their discriminating taste in household appointments would nonetheless distinguish themselves from their neighbors. Eden is obviously correct when she notes that the Carrolls did not flaunt their wealth by cooking "French, Chinese, or any other type of food," but her assertion that replicating a British gentlemen's diet in colonial America was not evidence of extravagance in quantity nor quality is unsupported by the evidence (given that we do not have their menus) and is belied by the specialized serving dishes they owned and the teas they imported (p. I 52 ).

Some contradictions are, in part, the messy reality of historical study, but Eden rarely acknowledges and never addresses these methodological challenges. Eden's account would carry more water if she were circumspect about the difficulties of attributing philosophical commitments to colonial subjects and explained the process by which examples were selected. Eden's book would also gain credibility from a more thorough engagement with the existing literature on colonial dining, a literature that, in contrast with Eden, tends to view dining as less about balance and ideas, and more about material progress. James E. McWilliams's argumentative A Revolution in Eating (2005), a study of colonial dining that sees food as integral to Americans effort to define themselves as a nation, is referenced once and unconvincingly dismissed in a single sentence. Keith Stavely and Kathleen Fitzgerald's encyclopedic account of New England foodways, America's Founding Foods (2004), is not even noted in the bibliography. These oversights are significant, for engaging McWilliams, Stavely, and Fitzgerald, social historians of eating who view the history of dining in the United States as a tale of makeshift progress, would offer Eden a clear-cut opportunity to demonstrate that the intellectual history of culinary ideas genuinely matters.

Eden has opened a new door for food studies in the early United States, one that challenges us to think seriously about how science and philosophy shaped the choices people made when they sat down at the table for dinner. Her treatment of humoral and mechanical ideas of the body should influence historians of both the United States and Europe, but it will take another book (perhaps a sequel by Eden) to fully explain how the ideas of the mind influenced the life of the stomach. 